\title{
Complete mitochondrial genome of the speckled dace Rhinichthys osculus, a widely distributed cyprinid minnow of western North America
}

\author{
Samantha L. Bock, Morgan M. Malley, and Sean C. Lema \\ Department of Biological Sciences, Center for Coastal Marine Sciences, California Polytechnic State University, San Luis Obispo, CA, USA
}

\begin{abstract}
The speckled dace Rhinichthys osculus (order Cypriniformes), also known as the carpita pinta, is a small cyprinid minnow native to western North America. Here, we report the sequencing of the full mitochondrial genome (mitogenome) of $R$. osculus from a male fish collected from the Amargosa River Canyon in eastern California, USA. The assembled mitogenome is 16658 base pair (bp) nucleotides, and encodes 13 protein-coding genes, and includes both a $12 \mathrm{~S}$ and a $16 \mathrm{~S}$ rRNA, 22 tRNAs, and a 985 bp D-loop control region. Mitogenome synteny reflects that of other Ostariophysian fishes with the majority of genes and RNAs encoded on the heavy strand (H-strand) except nd6, tRNA ${ }^{-G / n}, t R N A^{-A l a}, t R N A^{-A s n}, t R N A^{-C y s}, t R N A^{-T y r}, t R N A^{-S e r}, t R N A^{-G l u}$, and $t R N A^{-}$

Pro. The availability of this $R$. osculus mitochondrial genome - the first complete mitogenome within the lineage of Rhinichthys riffle daces - provides a foundation for resolving evolutionary relationships among morphologically differentiated populations of $R$. osculus.
\end{abstract}

\author{
Keywords \\ Cyprinidae, Cypriniformes, Leuciscinae, \\ mitogenome, mtDNA
}

The speckled dace Rhinichthys osculus (Girard, 1856) is a small fish within the Leuciscinae subfamily of true minnows (Cyprinidae, Cypriniformes). The native range for $R$. osculus extends from the Columbia River basin of southwestern Canada, through the western United States of America (USA), and into the Sonora region of northern Mexico (La Rivers, 1962; Minckley, 1973; Moyle, 2002; Scott \& Crossman, 1998). Rhinichthys osculus occurs in ecologically diverse habitats from groundwaterfed springs to rivers, and populations can vary extensively in morphological traits (Oakley et al., 2004; Sada et al., 1995; Woodman, 1992). Rhinichthys osculus was originally described across its range as at least 18 distinct species (e.g., Cope, 1874; Girard, 1856; Hubbs \& Kühne, 1937; Jordan \& Evermann, 1896), although it is now considered a single species comprised of morphologically distinct subspecies and populations.

Here, we describe the first complete mitochondrial genome of $R$. osculus. An adult male R. osculus (Amargosa Canyon spp.; Deacon \& Williams, 1984) measuring $68.20 \mathrm{~mm}$ SL and $5.17 \mathrm{~g}$ body mass was collected on 27 June 2015 from the Amargosa River near Tecopa, CA, USA (N 35 50.976’ N 116 $\left.13.851^{\prime} \mathrm{W}\right)$. DNA was extracted from skeletal muscle tissue (DNeasy Blood

Correspondence: Sean Lema, Department of Biological Sciences, California Polytechnic State University, 1 Grand Avenue, San Luis Obispo, CA 93407, USA. Tel: $1+805756$ 2802. E-mail: slema@calpoly.edu and Tissue Kit; Qiagen, Valencia, CA) and amplified (GoTaq ${ }^{\circledR}$ Long PCR Master Mix, Promega Corp., Madison, WI) using primers designed to available partial mtDNA regions of $R$. osculus (GenBank accession nos. AF081863, EU780582, EU158227, KF421812, HQ579004, DQ990249, DQ990314, AY366299, and FJ748866). The resulting PCR products were Sanger sequenced (Molecular Cloning Laboratory, South San Francisco, CA) and assembled (Sequencher v5, Gene Codes Corp., Ann Arbor, MI).

The complete mitogenome of $R$. osculus (KT424924) is $16658 \mathrm{bp}$ nucleotides in length with a composition of 13 protein coding genes, 22 tRNAs, and 2 rRNAs, as has been observed in other teleost fish mitogenomes. Nucleotide composition of the $\mathrm{H}$-strand of the full $R$. osculus mitogenome is $28.43 \% \mathrm{~A}, 18.18 \%$ $\mathrm{G}, 26.84 \% \mathrm{~T}$, and $26.55 \% \mathrm{C}$, with a combined $\mathrm{G}+\mathrm{C}$ content of $44.73 \%$. Phylogenetic analysis confirmed $R$. osculus belongs to what is referred by Simons et al. (2003) as the Open Posterior Myodome (OPM) clade of the Leuciscinae subfamily of 'true minnows' within the Cyprinidae (Figure 1) (Imoto et al., 2013; Mayden et al., 2009).

One described subspecies of $R$. osculus is extinct (R. o. reliquus; Burkhead, 2012; Miller et al., 1989), five subspecies have legally imperiled status (Gould \& Kaya, 1991; Williams \& Sada, 1985), and other populations appear distinct morphologically, but do not yet have a subspecies trinomen (Deacon \& Williams, 1984; Sada et al., 1995). There is also evidence that at least one habitat may support genetically-isolated sympatric populations of $R$. osculus (Pfrender et al., 2004). This complete mitogenome for $R$. osculus will enable future genetic studies into whether such populations are indeed distinct evolutionary lineages. 


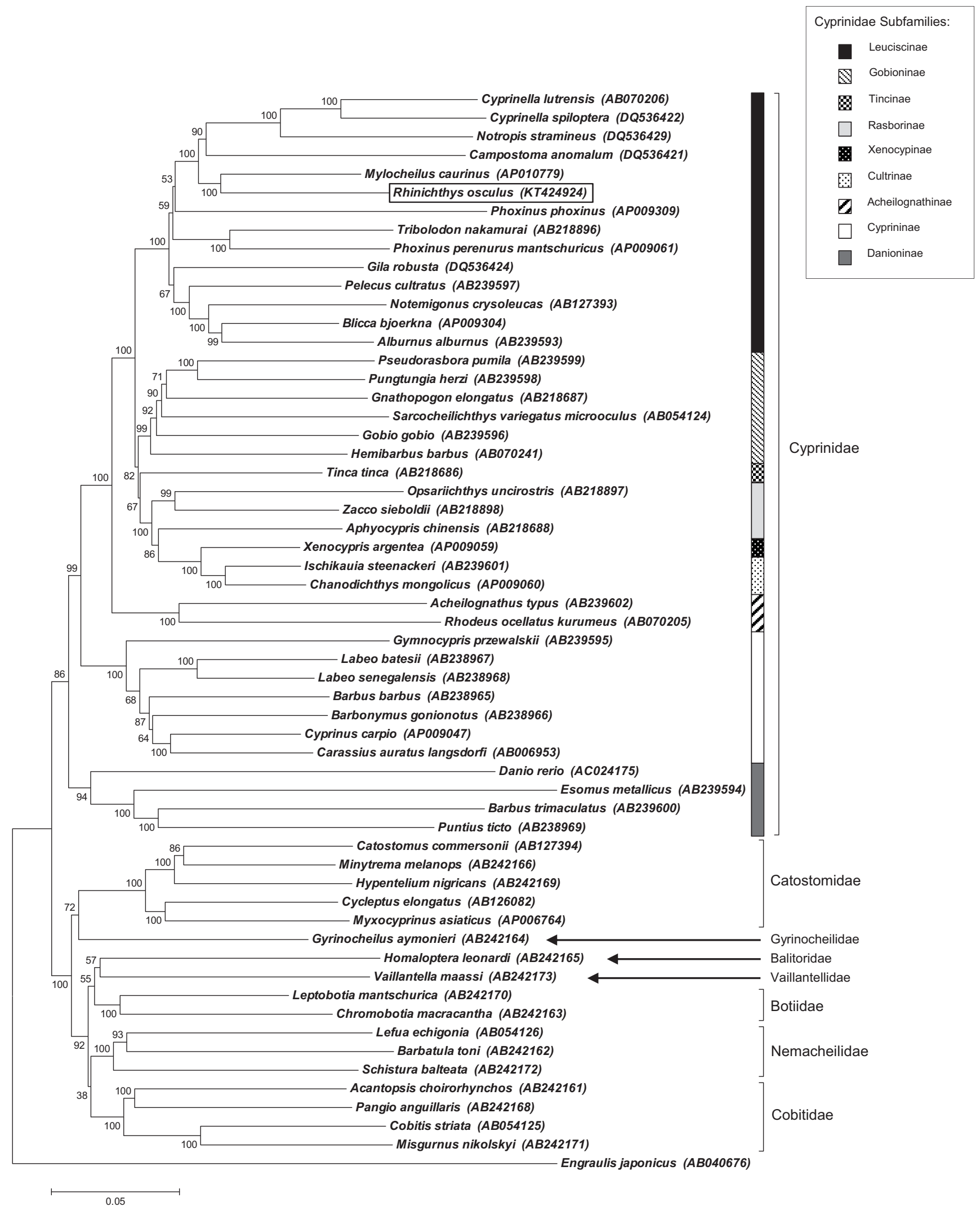

Figure 1. Neighbor-joining phylogenetic tree of the complete mitogenome of $R$. osculus (GenBank accession no. KT424924) and other Cypriniform fishes. Complete nucleotide sequences for each species were aligned using Clustal X software, and the tree was constructed using all nucleotide sites with a maximum likelihood model and pairwise gap deletion using MEGA v5.1 (Tamura et al., 2011). The $R$. osculus mitogenome is indicated by enclosure within the box. Japanese anchovy (Engraulis japonicus, Order Clupeiformes) was used as the outgroup. Bootstap values (1000 replicates) are shown for each node, and GenBank accession numbers are provide in parentheses accompanying each species name. Families within the order Cypriniformes are indicated by brackets, and subfamily designations within the family Cyprinidae are demarked by the color and pattern categories. Based on this phylogenetic analysis, $R$. osculus belongs to the Leuciscinae subfamily of 'true minnows' within the Cyprinidae. 


\section{Declaration of interest}

This research was supported by the CSU Program for Education and Research in Biotechnology (CSUPERB) and by the Cal Poly Frost Scholar program. The authors report that they have no conflicts of interest and are solely responsible for the content and writing of this manuscript.

\section{References}

Burkhead NM. (2012). Extinction rates in North American freshwater fishes, 1900-2010. BioScience 62:798-808.

Cope ED. (1874). On the Plagopterinae and the ichthyology of Utah. Proc Am Phil Soc 14:129-39.

Deacon JE, Williams JE. (1984). Annotated list of the fishes of Nevada. Proc Biol Soc Wash 97:103-18.

Girard CF. (1856). Researches upon the cyprinoid fishes inhabiting the fresh waters of the United States, west of the Mississippi Valley, from specimens in the museum of the Smithsonian Institution. Proc Acad Nat Sci Phila 8:165-213.

Gould WR, Kaya C. (1991). Pharyngeal teeth in the endangered Kendall Warm Springs dace (Rhinichthys osculus thermalis). Copeia 1991: 227-9.

Hubbs CL, Kühne ER. (1937). A new fish of the genus Apocope from a Wyoming warm spring. Occas Papers Mus Zool Univ Michigan 343: $1-21$.

Imoto JM, Saitoh K, Sasaki T, Yonezawa T, Adachi J, Kartavtsev YP, Miya M, et al. (2013). Phylogeny and biogeography of highly diverged freshwater fish species (Leuciscinae, Cyprinidae, Teleostei) inferred from mitochondrial genome analysis. Gene 514:112-24.

Jordan DS, Evermann BW. (1896). The fishes of North and Middle America: a descriptive catalogue of the species of fish-like vertebrates found in the waters of North America, north of the Isthmus of Panama. Bull US Natl Mus 47:1-1240.

La Rivers I. (1962). Fishes and fisheries of Nevada. Reno, NV: Nevada Fish and Game Commission.

Mayden RL, Chen W-J, Bart HL, Doosey MH, Simons AM, Tang KL, Wood RM, et al. (2009). Reconstructing the phylogenetic relationships of the earth's most diverse clade of freshwater fishes - order
Cypriniformes (Actinopterygii: Ostariophysi): A case study using multiple nuclear loci and the mitochondrial genome. Mol Phylogenet Evol 51:500-14.

Miller RR, Williams JD, Williams JE. (1989). Extinctions of North American fishes during the past century. Fisheries 14:22-38.

Minckley WL. (1973). Fishes of Arizona. Phoenix, AZ: Arizona Game and Fish Department.

Moyle PB. (2002). Inland fishes of California. Berkeley, CA: University of California Press.

Oakley DD, Douglas ME, Douglas MR. (2004). Small fish in a large landscape: Diversification of Rhinichthys osculus (Cyprinidae) in western North America. Copeia 2004:207-21.

Pfrender ME, Hicks J, Lynch M. (2004). Biogeographic patterns and current distribution of molecular-genetic variation among populations of speckled dace, Rhinichthys osculus (Girard). Mol Phylogenet Evol 30:490-502.

Sada DW, Britten HB, Brussard PF. (1995). Desert aquatic ecosystems and the genetic and morphological diversity of Death Valley system speckled dace. Am Fish Soc Symp 17:350-9.

Scott WB, Crossman EJ. (1998). Freshwater fishes of Canada. Oakville, ON: Galt House Publications LTD.

Simons AM, Berendzen PB, Mayden PL. (2003). Molecular systematics of North American phoxinin genera (Actinopterygii: Cyprinidae) inferred from mitochondrial $12 \mathrm{~S}$ and $16 \mathrm{~S}$ ribosomal RNA sequences. Zool J Linn Soc 139:63-80.

Tamura K, Peterson D, Peterson N, Stecher G, Nei M, Kumar S. (2011). MEGA5: Molecular evolutionary genetics analysis using maximum likelihood, evolutionary distance, and maximum parsimony methods. Mol Biol Evol 28:2731-9.

Williams JE, Sada DW. (1985). Status of two endangered fishes, Cyprinodon nevadensis mionectes and Rhinichthys osculus nevadensis, from two springs in Ash Meadows, Nevada. Southwestern Naturalist 30:475-84.

Woodman DA. (1992). Systematic relationships within the cyprinid genus Rhinichthys. In: Mayden RL, editor. Systematics, historical ecology, and North American Freshwater fishes. Stanford, CA: Stanford University Press. p 374-91. 